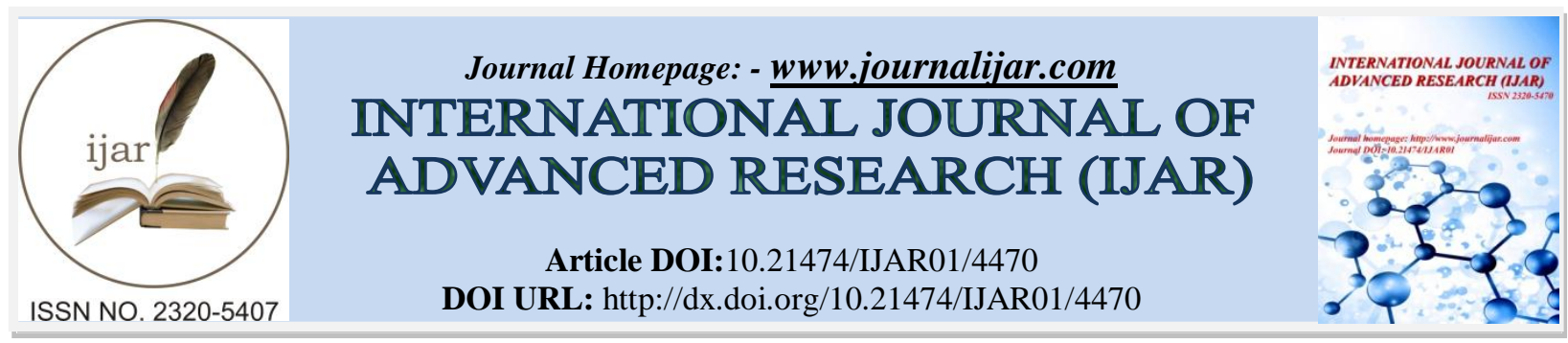

RESEARCH ARTICLE

\title{
CONSUMER PROTECTION IN INDIA - A SPECIAL REFERENCE TOTHE RIGHT TO SAFETY.
}

Dr. Sunitha Kanipakam.

Asst. Professor, Dept. of Law, Sri Padmavati Mahila Visvavidyalayam (Women's University), Tirupati-517502.

\section{Manuscript Info}

Manuscript History

Received: 13 April 2017

Final Accepted: 15 May 2017

Published: June 2017

\section{Abstract}

Copy Right, IJAR, 2017, All Rights reserved.

In a market economy where commercial firms compete to sell their goods and services to the consumers, more often resort to exploit the consumers by adopting unscrupulous, unfair and restrictive trade practices. Consumers are a weak party in buying goods and services as compared to the manufacturers and traders. As most of the consumers are being lured by the deceptive advertisements exaggerating the content, quality and effects of their goods or products and services, they require legal support against such exploitation, hoarding \& black-marketing. For that reason, even in a free market economy consumer needs protection for his rights by a legal authority. So that erroneous vendors are to be brought to legal action. A person, who is a consumer, may sue a hospital for medical negligence; an Architect for a faulty design as it becomes hazardous occupation; or a building contractor for defective work and an electricity for unsafe service due to defective work. During this process of legal claim professional expertise is involved. In such cases, a professional like a doctor, or an architect or an engineer may be more suitable than an advocate. So, both the parties have been given an option to choose from an advocate or any other person who may even be a professional expert in the particular field.

Consumers in the developed countries such as the USA and UK are much more conscious of their rights than developing countries. But in countries such as India, because of poverty, illiteracy and lack of awareness of legal rights consumers are quite a vulnerable for defective, adulteration and unsafe products. As a result, manufacturers and suppliers of goods and services generally exploit the consumers by adopting unfair and restrictive trade practices. In India, in exercise of the powers conferred by Article 145 of the Constitution and all other powers enabling it in this behalf, the Supreme Court with the approval of the President of India, made the rules called the Supreme Court (First Amendment) Rules, 1990. Now a day's Internet Marketing is really in lead so the necessity of effective implementation of the CP Act especially in this particular area. The consumer purchases goods or services by seeing an image on the screen and trusts the specification cited by the vender. The buyer cannot have physical access to the commodity before getting delivery. Now, in case the goods/services are not in conformity with the specification, protection is provided to the buyer through establishment of special court and by introduction of special legislation.

As consumers we have much concern about the money, choice, health and safety of the life. Market is always dominated by the sellers and their attitude towards consumers as weaker section. In last few years' market is found to be influenced by the false, misleading advertisements or representations, bargaining, offering gifts, prizes, 
contests and hoardings attracting public for product or services ${ }^{1}$. In the decade of 1960 number of legislations was introduced in Britain for the protection of consumers. The Consumer Safety Act, 1978 is one of such. In USA the consumer movement developed in the beginning of $19^{\text {th }}$ century and much more to this the Donald C. MacPherson's case $^{2}$ has contributed for a significant increase in consumer awareness. In this case the New York Court of Appeal has observed that a car manufacturer had to compensate a consumer who had been injured when one of the car wheels collapsed because of defect. Further, the court held that the manufacturer had been negligent because the defect could have been discovered by reasonable inspection. In 1972, the Consumer Product Safety Act was enacted.

\section{The United Nations Guidelines for Consumer Protection (UNGCP) ${ }^{3}$ :-}

Realising the helplessness of the consumers and necessity to protect their legitimate rights, the United Nations General Assembly in the year 1985 made some Guidelines to the member states to adopt preventive, protective and curative measures for the benefit of consumers. Later, these were expanded by the Economic and Social Council in 1999, and recently the General Assembly has revised the existing guidelines in 2015.

The growing importance of the consumer rights awareness across the world lead to form consumer associations in many countries, with Consumers International known as the International Organisation of Consumer Unions and acting as interlocutor with the United Nations. These guidelines constitute a comprehensive policy framework outlining government's responsibility to promote consumer protection in the areas of Physical safety; Protection and Promotion of the consumer economic interest; Standards for the safety and quality of consumer goods and services; Distribution facilities for consumer goods and services; Measures enabling consumers to obtain redress; Measures relating to specific areas (food, water and pharmaceuticals); and (vii) Consumer education and information programme. Though not legally binding, the guidelines provide an internationally recognized set of basic objectives particularly for governments of developing and newly independent countries for structuring and strengthening their consumer protection policies and legislations. UNGCP are "a valuable set of principles for setting out the main characteristics of effective consumer protection legislation, enforcement institutions and redressal systems and for assisting interested Member States in formulating and enforcing domestic and regional laws, rules and regulations that are suitable to their own socio- economic and environmental circumstances.

\section{Meaning of Consumer:-}

The Word "Consumer" is a derivative of the Latin word Consumere which means, "to take up totally or to eat'. The consumer is one who consumes or uses any commodity or service available to him either from natural resources or through a market. According to John F. Kennedy, "Consumer by definition includes every one. There are the largest economic grope affecting and affected by almost every public and private economic decision".

Consumer means ${ }^{4}$ any person who buys the goods for the consideration or hires the services by paid or promised or partly paid or party promised or it may be under a system of deferred payment. So, consumer is a person ${ }^{5}$ who hires the services or buys the goods for the consideration. Moreover, any beneficiary of such services, using the services or goods with approval of purchaser is also considered as consumer. Apart from this, in various cases, National Commission had declared that, a tax payer to municipality, Contractors, Applicants for jobs, a person who files suits in courts would not be considered as consumer.

\section{Objective:-}

The objective of the CP Act was well explained by the Supreme Court in M/S. Spring Meadows Hospital's case ${ }^{6}$ that, the parliament enacted the Consumer Protection Act to create a framework for speedy disposal of consumer disputes and to remove the existing evils of the ordinary court system. The Act being a beneficial legislation intended to confer some speedier remedy on a consumer from being exploited by unscrupulous traders, the provisions thereof should receive a liberal construction. Consumer protection is necessary even in a controlled economy where public enterprises play a dominant role since consumers are likely to be denied their rights ${ }^{7}$.

\section{The Consumer Protection Act, 1986 and its importance:-}

To fulfill the valuable set of principles of UNGCP, for setting out the main characteristics of an effective consumer protection legislation, enforcement institutions and redressal systems the government of India has enacted the Consumer Protection Act, 1986. This Act is a benevolent social legislation which lays down the rights of the consumers and provides adequate provisions for promotion and protection of the rights of the consumers. This Act has enabled ordinary consumers to secure less expensive and often speedy redressal of their grievances. By spelling out the rights and remedies of the consumers in a market so far dominated by organized manufacturers and traders of 
goods and providers various types of services ${ }^{8}$, the legislation makes the dictum, caveat emptor ('Buyer Beware') an issue of the past.

Although businessman is aware of his social responsibilities even then we come across many cases of consumer exploitation. Therefore it is necessary for the government of India to provide following rights to all the consumers under the Consumer Protection Act the Right to Safety; Right to Information; Right to Choice; Right to be Heard or Right to Representation; Right to Seek Redressal; and Right to Consumer Education. To ensure their rights it is very important to Organize, provide market information, protect from Misleading Advertisements, ensure physical Safety and informing Consumers about their basic rights. Among the above rights Right to Safety is the first one.

\section{Consumers' Right to Safety':-}

The Consumer Protection Act 1986 safeguards the various rights of Consumers, among those rights to safety of consumer under section 6, which covers a wide variety of products and services that are available in the market owing to technological advances, require safe handing. The use of some of these products requires technical knowledge. Many consumers may not be aware of the safe use of the products. They may also lack technical knowledge to assess the safety aspects of products and services. Therefore, product safety from the consumer's point of view is a matter of utmost importance.

\section{Meaning of the right to safety:-}

The right to safety means the right to be protected against product production process and services which are hazardous to health or life. It includes concern for term interests and immediate requirements of consumers. When purchased a good or availed a service, the consumer has a right to get himself of her protected against damage to his property and person. It should not cause any physical danger, health hazard or put the consumer in any difficulty because of failure. If should satisfy the consumer in terms of its quality and safety

According to this right the consumers have the right to be protected against the marketing of goods and services which are hazardous to life and property, this right is important for safe and secure life. This right includes concern for consumer's long term interest as well as for their present requirement. Sometimes the manufacturing defects in pressure cookers, gas cylinders and other electrical appliances may cause loss to life, health and property of customers. This right to safety protects the consumer from sale of such hazardous goods or services ${ }^{10}$. The Supreme Court of India, while dealing with the case of U.P. Power Corporation Ltd. \& Ors v. Anis Ahmad ${ }^{11}$, elaborately discussed the meaning and definition of Complaint provided under Section 2(1) (c) and the meaning of consumer provided under section 2(d) of the Consumer Protection Act. Further, the apex court has discussed about the consumers' rights to safety to a person or unsafe to public are being affected by the service provider with due diligence such person (consumer) can file a case.

Therefore, it is only in respect to aforementioned aspects that a consumer can file a complaint for the grievance suffered because of Unfair trade practice or restrictive trade practice, defective goods service, Deficiency in services, Hazardous goods and services and a price in excess of the price fixed under any law etc. The consumers are entitled to protection of their health and safety from the goods and services they buy. They should not be supplied goods or services which are hazardous to their health and safety.

\section{United Nations Guidelines on Safety:-}

The UN guidelines gave important legitimacy to the principles of consumer rights and practical support and guidance for governments for developing national consumer protection measures such as legal system, safety regulations, national or international standards, voluntary standards and the maintenance of safety records to ensure that products are safe in use. The Guidelines mentioned that suppliers, exporters, importers, retailers and the like would ensue that while in their care these goods are not rendered unsafe through improper handling or storage as they are responsible for bringing goods to the market. Further, Consumer should be instructed in the proper use of goods and should be informed for the risks involved in. Appropriate polices should ensure that if manufacturers or distributors become aware of unforeseen hazards after products are placed in the market, they should notify the relevant authorities and the public without delay.

Governments should also consider ways of ensuring that consumers are properly informed of such hazards. Vital safety information should be conveyed to consumers by internationally understandable symbols wherever possible. The Government should adopt policies under which, if a product is found to be seriously defective and or to 
constitute a substantial and severe hazard even when properly used, manufacturers and or distributors should replace or modify it, or substitute another product for it. If it is not possible to do so within a reasonable period of time, the consumer should adequately be compensated.

\section{Safety Standards:-}

In its guidelines in 1999 UNGCP highlighted the importance of standards for the safety and quality of consumer goods. National standards and regulations for product safety and quality should be reviewed from time to time, in order to ensure that they conform, where possible, to generally accepted international standards. Safety standards are intended to specify protection against different kinds of hazards like: Mechanical hazards, Electrical hazards, Thermal hazards, Fire or Explosion hazards, Chemical hazards, Biological hazards, Radiation hazards ${ }^{12}$.

\section{Standard Certification Marks:-}

Bureau of Indian Standards (BIS) plays a vital role in preparing standards for safety and quality. BIS has a regular interaction with various Governmental and non-Governmental agencies. The standards and ISI marks are promoted by the Bureau after discussions with various organizations by organizing seminars, participating in seminars and through print and electronic media. Standard or a certification mark on the product is an indication of guarantee of safety in its use. It is an assurance of the fact that the product has passed through certain standardized tests and it ensures safety against health ${ }^{13}$

\section{The National Consumer Disputes Redressal Commission:-}

The CP Act mandates establishment of Consumer Protection Councils ${ }^{14}$ at the Centre as well as in each State and District, with a view to promoting consumer awareness. The National Consumer Disputes Redressal Commission (NCDRC), India is a quasi-judicial commission in India which was set up in 1988. According to Section 21 posits that the National Consumer Disputes Redressal Commission ${ }^{15}$ shall have jurisdiction to entertain a complaint valued more than one crore and also have Appellate and Revisional jurisdiction from the orders of State Commissions or the District fora as the case may be. Section 23 of Consumer Protection Act, 1986, provides that any person aggrieved by an order of NCDRC, may prefer an Appeal against such order to Supreme Court of India within a period of 30 days.

\section{Conclusion:-}

The growing interdependence of the world economy and international character of many business practices have made emphasis on consumer protection and promotion. Now, Consumers, all over the world, are demanding value for their hard earn money in the form of quality goods and better services. It is true that modern technological developments have made a great impact on the quality, availability and safety of goods and services. But the fact of the matter is that the consumers are still victims of unfair and restrictive trade practices adopted by trader or manufacturer. The Intergovernmental group of experts on consumer protection law and policy has been established to monitor the implementation of the guidelines, provide a forum for consultations, produce research and studies, provide technical assistance, undertake voluntary peer reviews, and periodically update the UNGCP with an avowed objective to promote international enforcement cooperation among Member States and encouraging the sharing of experiences in consumer protection.

1. Nagnath Chandrakant Borphalkar ,Consumer Justice In India, legalservicesindia .com

2. MacPherson v. Buick Motor Co., 217 N.Y. 382, 111 N.E. 1050 (1916) is a famous New York Court of Appeals opinion by Judge Benjamin N. Cardozo

3. www.un.org/esa/sustdev/publications/consumption_en.pdf

4. Section 2(d) of the Consumer Protection Act-1986

5. (m) "person" includes, - (i) a firm whether registered or not; (ii) a Hindu undivided family; (iii) a cooperative society;

6. M/S. Spring Meadows Hospital's case \& Anr Versus Harjol Ahluwalia Through, K.S. Ahluwalia \& Anr [AlR 1998 SC 1801; (1998) 4 SCC 39]

7. Consumer Protection in India: Needs and Methods, Article shared by subho mukher jee

8. Hon'ble Mr. Justice D. K. Jain, President, The National Consumer Disputes Redressal Commission (NCDRC), India 
9. Sec.6(a) the right to be protected against the marketing of goods and services which are hazardous to life and property

10. Consumer Rights under the Consumer Protection Act, India, Article shared by Utkarsh Dayal

11. SC 2012, Aug. 29

12. http://hdl.handle.net/10603/54415, A Study of Consumer Movement In Selected Districts Of Maharashtra, 2015, Researcher: Gaikwad, Navnath Sopanra

13. The Bureau of Indian Standards is the national Standards Body of India established by the Act no. 63 of 1986, working under the aegis of Ministry of Consumer Affairs, Food \& Public Distribution of Government of India. The organisation was formerly the Indian Standards Institution registered under the Societies Registration Act, 1860, set up under the Resolution of the then Department of Industries and Supplies No. 1 Std.(4)/45, dated 3 September 1946.

14. Chapter II of the CP Act from section 4 to $8 \mathrm{~A}$

15. The Consumer Protection Act, 1986 